\title{
Analisis Faktor yang Mempengaruhi Keputusan Pembelian dan Implikasinya pada Minat Beli Ulang
}

\author{
Popo Suryana \\ Fakultas Ekonomi Universitas Pasundan \\ J1. Tamansari No. 6-8, Bandung 40116 \\ E-Mail: popsuryana@yahoo.co.id \\ Eliyandi Sumar Dasuki \\ Training and Development Manager JG Motor Group \\ E-Mail: eliandi_dasuki@jgmotorgroup.com
}

\begin{abstract}
This study aims to obtain empirical evidence about the "Effect of Service Quality and Store Image Purchase Decision And Implications On Repurchase Intention (A Survey On Consumer Motorcycles JG Motor Group in Bandung Region)". In addition, this study wanted to know how the quality of service, store image, and Yamaha Motorcycles purchasing decisions are the implications on repurchase intention JG Motor Group in Bandung region. The method used was a survey method with a descriptive and explanatory approach. Data collection using questionnaires to a sample of 200 customers. Analysis of data analysis using SEM (Structural Equation Modeling). The results showed that the quality of service, store image was rated by the majority of consumers are already good, so is the customer purchase decision and repurchase intention. Service quality and store image influences purchase decisions either simultaneously or partially, as well as influencing purchase decisions of consumers repurchase intention JG Motor Group in Bandung region.
\end{abstract}

Keywords: service quality, store image, purchase decision, repurchase intention.

\begin{abstract}
ABSTRAK
Penelitian ini bertujuan untuk memperoleh bukti empiris mengenai "Pengaruh Kualitas Pelayanan Dan Citra Toko Terhadap Keputusan Pembelian Dan Implikasinya Pada Minat Beli Ulang (Suatu Survei Pada Konsumen Sepeda Motor di JG Motor Group Wilayah Bandung)". Selain itu juga penelitian ini ingin mengetahui bagaimana kualitas pelayanan, citra toko, keputusan pembelian Sepeda Motor Yamaha yang implikasinya pada minat beli ulang di JG Motor Group Wilayah Bandung. Metode penelitian yang digunakan adalah metode survey dengan pendekatan deskriptif dan eksplanatori. Pengumpulan data dengan menggunakan kuesioner terhadap sebanyak 200 pelanggan sebagai sampel. Analisis data menggunakan Analisis SEM (Structural Equation Modeling). Hasil penelitian menunjukan bahwa kualitas pelayanan, citra toko dinilai oleh sebagian besar konsumen sudah baik, begitu juga mengenai keputusan pembelian konsumen dan minat beli ulang. Kualitas pelayanan dan citra toko mempengaruhi keputusan pembelian baik secara simultan maupun parsial, serta keputusan pembelian mempengaruhi minat beli ulang konsumen pada JG Motor Group Wilayah Bandung.
\end{abstract}

Kata Kunci: kualitas pelayanan, citra toko, keputusan pembelian konsumen, minat beli ulang. 


\section{PENDAHULUAN}

Kemajuan teknologi dan informasi yang semakin berkembang menjadikan kebutuhan manusia ikut berkembang dan semakin kompleks. Perusahaan berlomba-lomba menciptakan produk untuk memenuhi kebutuhan dan keinginan pasar (konsumen) yang semakin beragam. Termasuk industri sepeda motor walaupun pasarnya terus tumbuh akan tetapi persaingan pada industri tersebut semakin ketat dengan munculnya vendor-vendor baru seperti Cina, India, dan Eropa

Industri sepeda motor merupakan industri yang sangat pesat perkembangannya saat ini. Hal ini ditandai dengan semakin banyaknya dealer yang ada pada setiap daerah termasuk di wilayah Kota Bandung. Potensi Kota Bandung yang besar dalam pemasaran sepeda motor menarik para produsen membuka dealer, akibatnya terjadi persaingan yang ketat. Lambin dalam Ferdinand (2002:5), menyebutkan bahwa untuk memenangkan persaingan pasar diperlukan model acuan strategis dengan melalui pengetahuan yang lebih baik tentang perilaku pembelian dan pembelian ulang konsumen, sehingga dari upaya ini nantinya dapat diharapkan tercapainya sasaran pemasaran yang berupa peningkatan porsi pasar (market share).

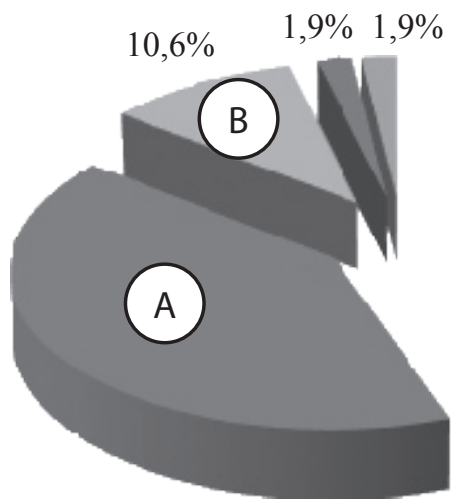

$41,29 \%$

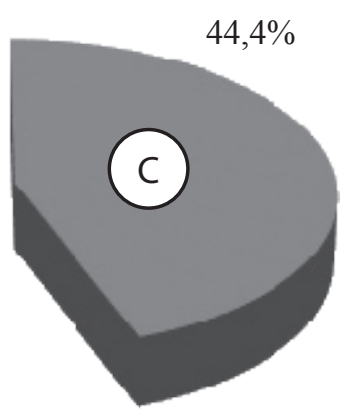

Market Share Tahun 2008
Gambar 1. menunjukkan bahwa total penjualan sepeda motor di Wilayah Bandung pada tahun 2012 mencapai 181.192 unit lebih rendah dibandingkan 2008 yang mencapai 185.856 unit. Pada tahun 2008 penjualan sepeda motor merek Yamaha masih mendominasi pasar di Wilayah Bandung dengan market share mencapai 44,4\%, sementara Honda, pesaing utamanya, pada tahun 2008 dengan market share sebesar 41,2\%. Akhir tahun 2012 posisi penjualan dari Yamaha mengalami penurunan yang drastis, sehingga market share-nya mencapai angka terendah yaitu sebesar 29,7\% jauh di bawah Honda yang justru mengalami peningkatan market share menjadi $60,7 \%$ di tahun 2012.

Penurunan market share Yamaha di Wilayah Bandung ini terjadi akibat dari penjualan di grup dealer utama mengalami penurunan, seperti dialami JG Motor Group yang terdiri dari enam dealer yaitu JG Asia Afrika, JG Kopo, JG Bandung, JG Cibeureum, JG Ujungberung, dan JG Ciwastra. Pesaing JG Motor Group datang dari dealer Yamaha lainnya seperti Arista Group, Fortuna Group, Deta Group, dan dealer Yamaha lainnya akan mempengaruhi volume penjualan dari JG Motor Group. Perkembangan jumlah penjualan JG Motor Group dapat dilihat pada Gambar 2.

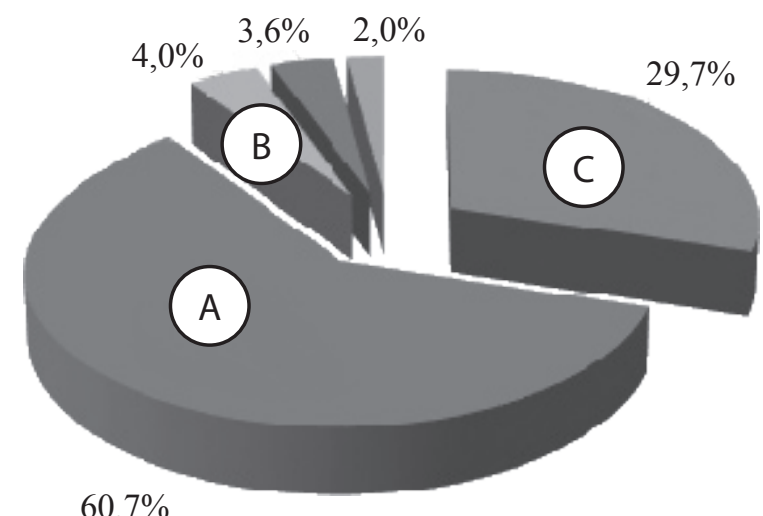

Market Share Tahun 2012

Keterangan:

A. Honda

B. Suzuki

C. Yamaha

Sumber: Polda Jabar

Gambar 1. Market Share Penjualan Sepeda Motor di Wilayah Bandung Periode tahun 2008 dan 2012 

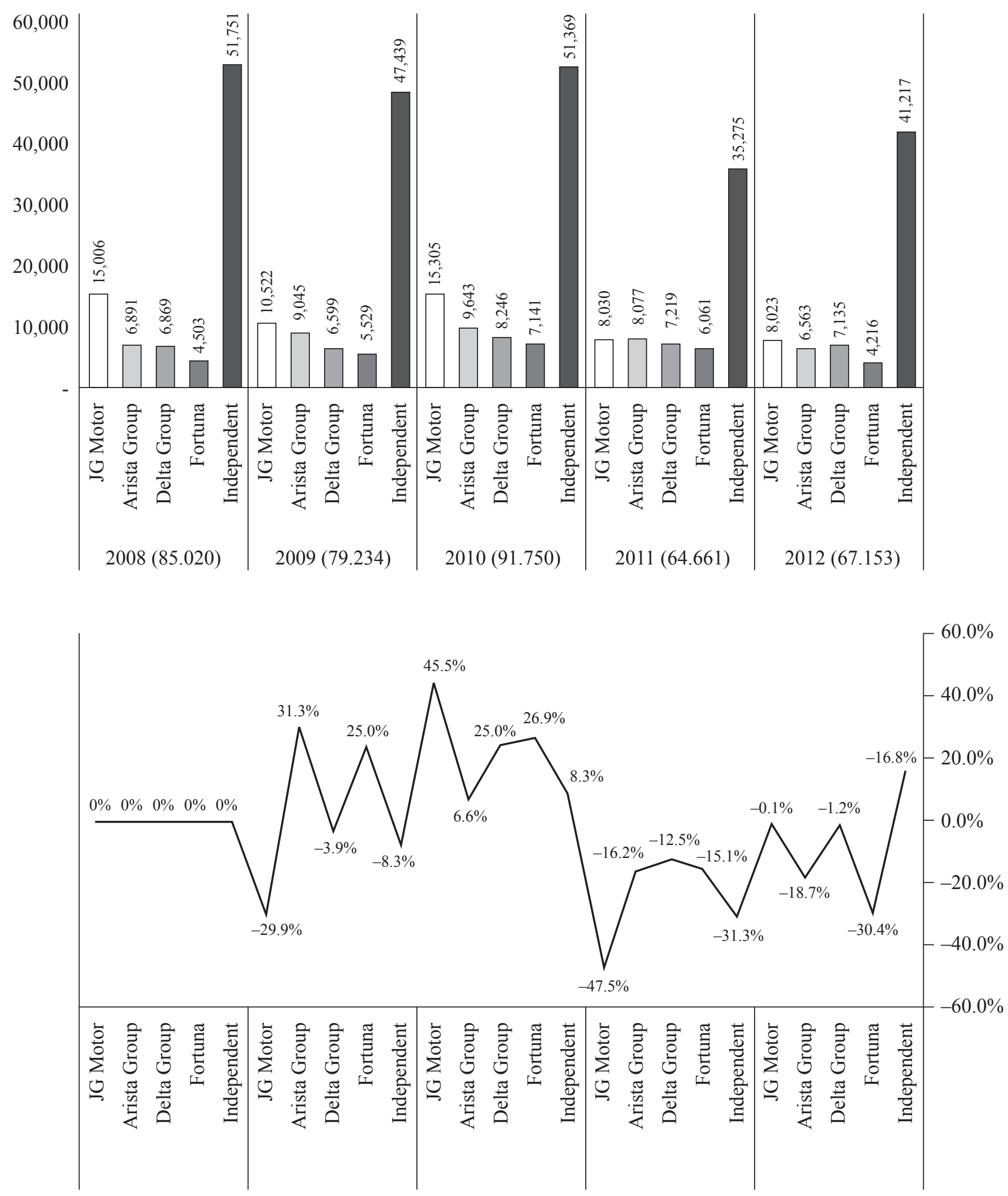

Sumber: YIMM, diolah

Gambar 2. Penjualan Sepeda Motor Yamaha di Wilayah Bandung Berdasarkan Main Dealer Periode tahun 2008-2012 
Gambar 2. menunjukkan bahwa jumlah penjualan dari JG Motor Group dalam lima tahun terakhir menunjukkan fluktuasi. Namun dalam tiga tahun terakhir di wilayah Bandung dan sekitarnya menunjukkan penurunan penjualan yang sangat drastis dari 15.305 unit di tahun 2010 turun menjadi 8.023 unit di tahun 2012. Kondisi ini menunjukkan bahwa keinginan konsumen untuk membeli sepeda motor merek Yamaha mengalami penurunan. Penurunan jumlah pembelian Sepeda Motor Yamaha di JG Motor Group selain diakibatkan oleh intensitas persaingan yang sangat ketat dengan merek lain juga akibat dari bertambahnya dealer Yamaha untuk area pemasaran yang sama. Kondisi ini tidak hanya menyebabkan volume penjualan sepeda motor dari JG Motor Group mengalami penurunan, tetapi juga minat konsumen untuk melakukan pembelian ulang yang terlihat dari repeat order konsumen pada JG Motor Group juga semakin berkurang.

Hasil evaluasi dari Marketing Support Department periode tahun 2011-2012 diperoleh informasi bahwa fluktuasi jumlah pembeli dari tahun 2011 sampai dengan 2012 disebabkan karena masih banyaknya keluhan konsumen yang diterima oleh JG Motor Group, karena keluhan pelanggan datang dari berbagai jenis permasalahan mulai dari harga, promosi, lokasi, produk, sampai layanan, dan fasilitas-fasilitas yang diberikan oleh dealer-dealer yang tergabung dalam JG Motor Group.

Tabel 1. menunjukkan bahwa total keluhan pelanggan berdasarkan hasil evaluasi Marketing Support Department mengalami peningkatan dari 269 di tahun 2011 menjadi 279 di tahun 2012 atau sebesar 3,71\% dari konsumen yang pernah melakukan pembelian. Padahal JG Motor Group menetapkan batas standar maksimun keluhan konsumen sebesar $0,5 \%$. Lebih tingginya persentase keluhan konsumen pada JG Motor Group dibandingkan standar yang telah ditetapkan menunjukkan bahwa persepsi konsumen terhadap kualitas pelayanan dan citra toko yang terbentuk masih belum memenuhi harapan manajemen perusahaan.

Aspek kualitas pelayanan yang masih banyak dikeluhkan pelanggan JG Motor Group adalah kejelasan informasi tentang STNK, BPKB, dan ketersediaan spare part secara online yang mencapai $21,15 \%$ lebih tinggi dibandingkan tahun 2011 yang mencapai 19,70\%. Keluhan konsumen atas sarana parkir mengalami peningkatan dari $19,33 \%$ menjadi $20,79 \%$ di tahun
2012. Fasilitas $J G$ value card untuk memudahkan konsumen melihat history kendaraan secara online juga masih susah untuk diakses. Kualitas pelayanan bukan hal yang baru dalam pemasaran jasa, bisanya kualitas pelayanan digunakan oleh praktisi-praktisi pemasaran di dalam aktivitas menarik pelanggan baru dengan memberikan pelayanan yang unggul atau makna baru pada pelayanan yang sudah ada.

Parasuraman dalam Lupiyoadi dan Hamdani (2007:148)mengemukakan bahwa Kualitas pelayanan merupakan ukuran penilaian menyeluruh atas tingkat suatu pelayanan yang baik. Kualitas pelayanan (service quality) sebagai hasil persepsi dari perbandingan antara harapan pelanggan dengan kinerja aktual pelayanan. Haynes (2006:184) menjelaskan lima aspek pada kualitas jasa yaitu avaliability of service, responsibility of service, reliability of service, Completness of service, dan profesionalism.

Citra toko merupakan persepsi konsumen terhadap suatu toko dibandingkan dengan toko lainnya. Masing-masing konsumen mempunyai persepsi yang berbeda antara toko yang satu dengan yang lainnya tergantung dari citra setiap toko.

Kotler (2007:173) menyatakan citra toko merupakan sikap dan tindakan seseorang terhadap suatu obyek sangat dikondisikan citra dari obyek tersebut. Citra toko merupakan persepsi konsumen atau perasaaan konsumen terhadap suatu toko maka hal yang samapun dapat dipandang berbeda oleh konsumen. Boemer dan Schroder (2002:124) menyatakan $A$ store image can be defined as the customer's perception of the store versus competitor stores. Jadi dapat diartikan citra toko adalah bagaimana persepsi konsumen terhadap suatu toko dibandingkan dengan toko lainnya. Masing-masing konsumen mempunyai persepsi yang berbeda antara toko yang satu dengan yang lainnya tergantung dari citra setiap toko.

Bloemer dan Schroder menyatakan citra toko dibangun dari elemen bauran pemasaran eceran. Komponen-komponen atribut pembentuk citra toko yaitu produk, pelayanan, atmosfer toko, dan promosi.

Keputusan pembelian konsumen menurut Kotler dan Keller terjemahan Sabran (2009:14) adalah tahap di mana konsumen juga mungkin membentuk niat untuk membeli produk yang paling disukai, di mana keputusan konsumen untuk memodifikasi, menunda, atau menghindar sangat dipengaruhi risiko yang dirasakan. 
Tabel 1. Keluhan Pelanggan JG Motor Group Tahun 2011-2012

\begin{tabular}{|c|c|c|c|c|c|}
\hline Klasifikasi Keluhan & Jenis Keluhan & Jumlah Keluhan 2011 & (\%) & Jumlah Keluhan 2012 & (\%) \\
\hline \multirow[t]{10}{*}{ Pelayanan } & Kontak pelanggan & & & & \\
\hline & - Customerhotline & 37 & 13,75 & 34 & 12,19 \\
\hline & $\begin{array}{l}\text { Informasi STNK, BPKB, } \\
\text { dan Spare part online }\end{array}$ & 53 & 19,70 & 59 & 21,15 \\
\hline & - Booking dan home service & 7 & 2,60 & 5 & 1,79 \\
\hline & - Website pembelian online & 6 & 2,23 & 7 & 2,51 \\
\hline & - JG value card & 26 & 6,67 & 29 & 10,39 \\
\hline & Profesionalisme karyawan & 9 & 3,35 & 10 & 3,58 \\
\hline & Fasilitas fisik & & & & \\
\hline & - Sarana parkir & 52 & 19,33 & 58 & 20,79 \\
\hline & - Ruang tunggu & 28 & 10,41 & 32 & 11,47 \\
\hline \multirow[t]{5}{*}{ Citra Toko } & Harga & 16 & 5,95 & 14 & 5,02 \\
\hline & Variasi produk & 13 & 4,83 & 11 & 3,94 \\
\hline & Lokasi & 8 & 2,97 & 7 & 2,51 \\
\hline & Atmosfir Toko & 9 & 3,35 & 10 & 3,58 \\
\hline & Program loyalty & 5 & 1,86 & 3 & 1,08 \\
\hline Total & & 269 & 100,0 & 279 & 100,0 \\
\hline
\end{tabular}

Sumber: Marketing Support Departement, 2012

Kotler dan Amstrong terjemahan Sabran (2009:63) mengemukakan bahwa konsumen banyak membuat keputusan pembelian setiap hari. Sebagian besar perusahaan meneliti konsumen yang melakukan pembelian untuk menjawab pertanyaan tentang apa yang dibeli konsumen, mereka membeli, bagaimana dan berapa banyak mereka membeli, kapan mereka membeli, dan mengapa mereka membeli. Pemasar dapat belajar secara nyata dari konsumen yang melakukan pembelian untuk mengetahui apa yang mereka beli, di mana, dan berapa banyak.

Menurut Kotler Keller terjemahan Sabran (2009:235) keputusan adalah sebuah proses pendekatan penyelesaian masalah yang terdiri dari pengenalan masalah, mencari informasi, beberapa penilaian alternatif, membuat keputusan membeli, dan perilaku setelah membeli yang dilalui konsumen. Tahap-tahap proses pembelian konsumen seperti pada Gambar 3.

Niat (intentions) dapat digambarkan sebagai suatu situasi seseorang sebelum melakukan suatu tindakan (action), yang dapat dijadikan dasar untuk memprediksi perilaku atau tindakan tersebut. Repurchase intention merupakan perilaku yang muncul sebagai respon terhadap obyek. Ketika seorang konsumen memperoleh respon positif atas tindakan masa lalu, dari situ akan terjadi penguatan, dengan dimilikinya pemikiran positif atas apa yang diterimanya memungkinkan individu untuk melakukan pembelian secara berulang.

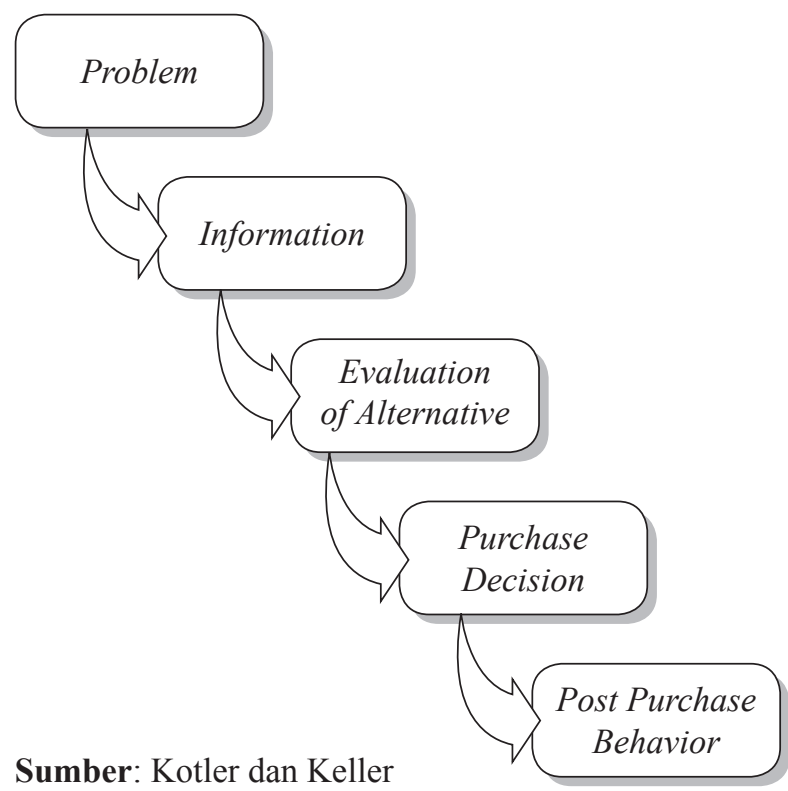
terjemahan Sabran (2009;35)

Gambar 3. Proses Keputusan Pembelian Konsumen 
Menurut Oliver (2010:435) "Repurchase intention based on favorable performance (cognitive) variables, favorable attitude (affective) variables, variable intention (cognative) variables, and repeat purchasing." Berdasarkan pengertian ini dapat dikatakan bahwa tedapat beberapa variabel yang mempengaruhi minat pembelian ulang yaitu variabel kinerja yang menguntungkan (cognitive), variabel sikap yang menguntungkan (affective), variabel niat (cognative), dan pembelian ulang.

Berdasarkan penjelasan tersebut dapat dikatakan bahwa repurchase intention adalah kecenderungan perilaku membeli dari konsumen pada suatu produk barang dan jasa yang dilakukan secara berulang jangka waktu tertentu dan secara aktif menyukai dan mempunyai sikap positif terhadap suatu produk barang atau jasa, didasarkan pada pengalaman yang telah dilakukan di masa lampau.

JG Motor Group, sebagai salah satu pelaku bisnis di bidang jasa pemasaran kendaran bermotor roda dua dengan merek Yamaha sangat menyadari perlunya strategi yang diterapkan untuk menghadapai pesaing dengan bidang cakupan yang sama. Sebagai perusahaan yang bergerak di bidang jasa penjualan kendaraan, JG Motor Group menyadari bahwa pelanggan adalah faktor paling penting dalam usaha tersebut. Peran manajemen pemasaran yang handal menjadi tulang punggung usaha ini. Perlu strategi pemasaran yang baik dan inovatif yang dapat menjaga kelangsungan usaha dengan menciptakan keputusan pembelian konsumen.

Proses keputusan pembelian merupakan proses penting yang dipengaruhi pemasar melalui strategi dan bauran pemasaran. Konsumen akan mengevaluasi keputusan dan tindakannya dalam membeli. jika suatu produk dibeli dengan percobaan ternyata memuaskan atau melebihi maka konsumen berkeinginan untuk melakukan pembelian ulang. Minat pembelian ulang dianggap sebagai fungsi dari sikap terhadap produk atau pelayanan. Sikap pelanggan terhadap pelayanan berdasarkan pada ekspektasi pelanggan terhadap kinerja perusahaan, dan sikap ini mempengaruhi minat pembelian ulang pada perusahaan.

Hubungan antara kualitas pelayanan dan keputusan pembelian dapat dikatakan bahwa suatu produk layanan, memiliki dampak pada kehendak untuk menggunakan layanan yang sama di masa yang akan datang. Karena pada dasarnya perilaku yang lampau dapat mempengaruhi minat (intention) secara langsung dan perilaku yang akan datang (future behavior). Hasil penelitian dari Bao et al. (2010) menemukan bahwa selain pengaruh tidak langsung melalui persepsi kualitas pelayanan, citra toko memiliki pengaruh langsung positif terhadap tindakan pembelian.

\section{METODE}

Berdasarkan tingkat eksplanasinya (level of explanation), penelitian ini termasuk dalam kategori penelitian deskriptif verifikatif. Unit analisis dalam penelitian ini adalah konsumen yang telah melakukan pembelian motor Yamaha di dealer-dealer tersebut. Dipilihnya JG Motor Group didasarkan pada kondisi data pembelian kendaraan sepeda motor merek Yamaha yang cenderung fluktuatif, namun mengalami penurunan dalam beberapa bulan terkahir, sehingga target penjualan dan market share masih lebih rendah dibandingkan pesaing.

Populasi dalam penelitian ini adalah jumlah pembeli Sepeda Motor Yamaha di wilayah Bandung dan sekitarnya pada JG Motor Group yang terdiri dari enam dealer yakni JG Asia Afrika, JG Kopo, JG Cibeureum, JG Ujung Berung, JG Bandung, dan JG Ciwastra. Penggunaan teknik pengambilan sampel dilakukan dengan cara yang convenience yaitu dengan mengirimkan kuesioner kepada para responden secara langsung maupun dan melalui wawancara secara langsung. Disisi lain teknik sederhana merupakan teknik pengambilan sampel yang efisien. Kriteria pengambilan sampel didasarkan pada hal-hal sebagai berikut:

1. Responden menggunakan sepeda motor Yamaha yang dibeli dari JG Motor Group.

2. Responden sekurang-kurangnya pernah datang kembali ke JG Motor Group untuk mencoba dan membeli kembali sepeda motor Yamaha.

Berdasarkan pandangan dan batasan tersebut, maka sampel yang diambil dalam penelitian ini adalah 160 responden.

Teknik analisis data yang digunakan pada penelitian ini adalah dengan menggunakan SEM (Structural Equation Modeling) dengan program AMOS (Analysis of Moment Structure). Menurut Ghozali (2005:1), SEM merupakan gabungan dari dua metode statistik yang terpisah yaitu analisis faktor dan model persamaan simultan. 


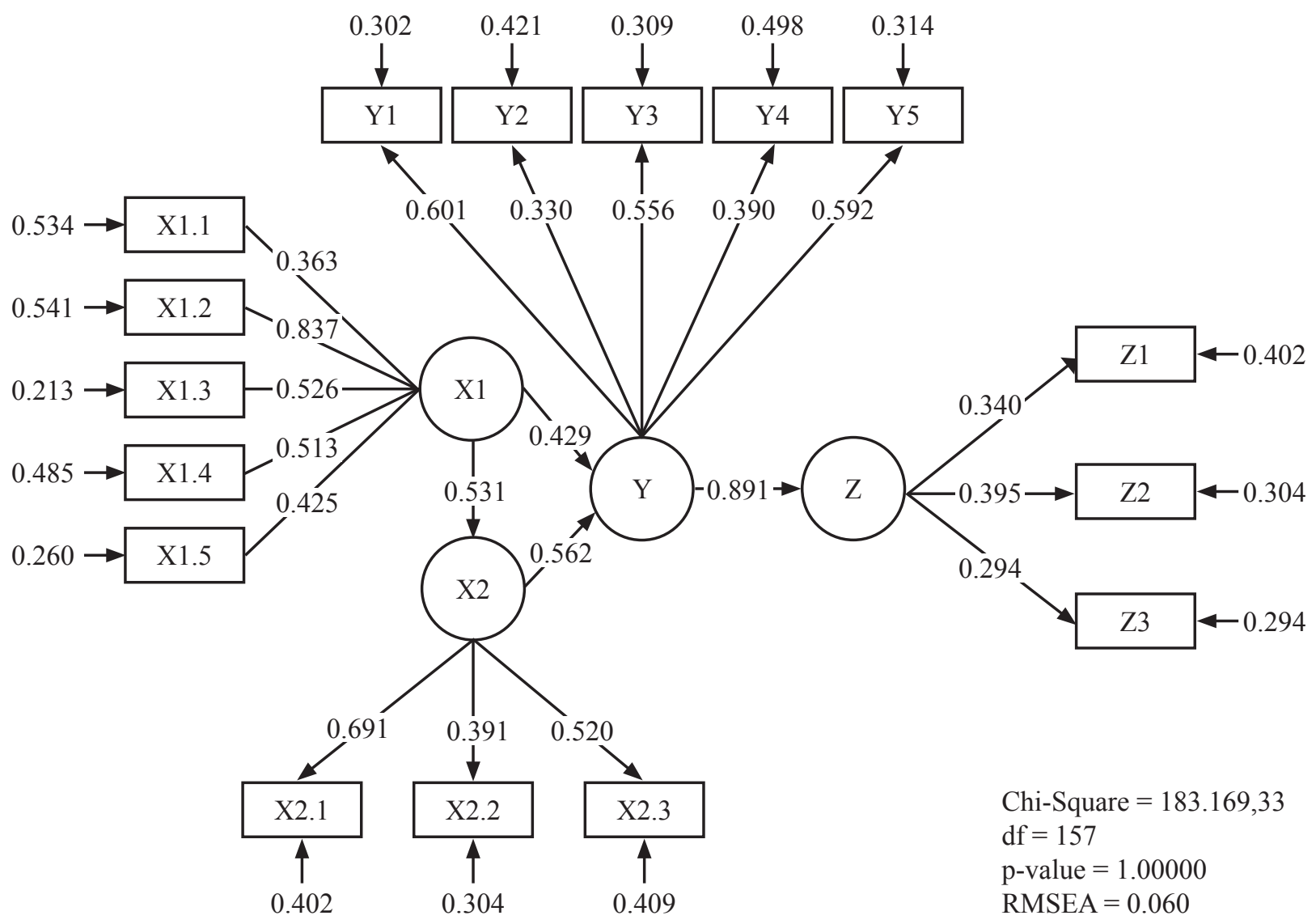

Gambar 4. Diagram Jalur Penelitian Pengaruh Kualitas Pelayanan dan Citra Toko terhadap Keputusan Pembelian dan Implikasinya Pada Minat Beli Ulang (Standardized Coefficient)

\section{HASIL}

Dalam penelitian ini dimaksudkan untuk mengukur seberapa besar pengaruh kualitas pelayanan dan citra toko terhadap keputusan pembelian dan implikasinya pada minat beli ulang konsumen dengan hasil perhitungan dapat dilihat pada Gambar 4.

\section{Pengaruh Kualitas Pelayanan dan Citra Toko Terhadap Keputusan Pembelian Konsumen}

Persamaan struktural untuk menjelaskan pengaruh kualitas pelayanan dan citra toko terhadap keputusan pembelian sebagai berikut: $\eta_{1}=0,429 \xi_{1}+$ $0,562 \xi_{2}$, Varians Error $=0,319$ dan $R^{2}=0,779$.

Model tersebut menunjukkan koefisien pengaruh dari kualitas pelayanan $\left(\xi_{1}\right)$ terhadap keputusan pembelian $\left(\eta_{1}\right)$ sebesar 0,429 dengan nilai t-hitung untuk uji statistik sebesar 3,309 dan koefisien pengaruh dari citra toko $\left(\xi_{2}\right)$ terhadap keputusan pembelian $\left(\eta_{1}\right)$ sebesar 0,562 dengan nilai t-hitung untuk uji statistik sebesar 6,507.

Setelah model disimpulkan diterima dan terdapat pengaruh signifikan dari kualitas pelayanan dan citra toko terhadap keputusan pembelian, selanjutnya adalah menjelaskan seberapa besar pengaruh dari kualitas pelayanan dan citra toko terhadap keputusan pembelian.

Secara lebih terinci dapat diketahui total pengaruh langsung dan tidak langsung kualitas pelayanan $\left(\xi_{1}\right)$ dan citra toko $\left(\xi_{2}\right)$ terhadap keputusan pembelian $\left(\eta_{1}\right)$ sebagai berikut:

Besar pengaruh dari kualitas pelayanan terhadap keputusan pembelian mencapai $32,40 \%$. Sehingga perubahan dalam kualitas pelayanan akan berdampak besar terhadap keputusan pembelian 
konsumen mencapai 32,40\%. Oleh karena itu, untuk meningkatkan keputusan pembelian pada sepeda motor di JG Motor Group harus diupayakan pula peningkatan pada kualitas pelayanan.

Besar pengaruh dari citra toko terhadap keputusan pembelian mencapai $45,58 \%$. Sehingga perubahan dalam citra toko akan berdampak besar terhadap keputusan pembelian konsumen mencapai $45,58 \%$. Oleh karena itu, untuk meningkatkan citra toko pada JG Motor Group harus diupayakan pula peningkatan pada citra toko.

Secara total diperoleh $77,98 \%$ perubahan keputusan pembelian dapat dijelaskan oleh variabel kualitas pelayanan dan citra toko, sehingga dapat disimpulkan bahwa variabel yang paling berperan dalam meningkatkan keputusan pembelian konsumen untuk membeli sepeda motor di JG Motor Group adalah citra toko dan sisanya yaitu sebesar $22,02 \%$ merupakan pengaruh yang berasal dari faktor-faktor lain.

\section{Pengaruh Keputusan Pembelian terhadap Minat Beli Ulang}

Persamaan struktural untuk menjelaskan pengaruh keputusan pembelian terhadap minat beli ulang sebagai berikut: $\eta_{2}=0,891 \eta_{1}$, Varians Error $=$ 0,2061 dan $R^{2}=0,7939$

Hipotesis yang diajukan yaitu pengaruh keputusan pembelian terhadap minat beli ulang. Total pengaruh keputusan pembelian terhadap minat beli ulang sebesar 79,39\%; menunjukkan bahwa variabel keputusan pembelian dapat mendorong terhadap peningkatan minat beli ulang konsumen.

Pengaruh keputusan pembelian $\left(\dot{\eta}_{1}\right)$ terhadap minat beli ulang $\left(\dot{\eta}_{2}\right)$ signifikan secara pengujian statistik karena nilai t ${ }_{\text {hitung }}$ untuk pengujian lebih besar dari t ${ }_{\text {tabel }}$. Hasil tersebut diperkuat dengan nilai total kontribusi yang diberikan oleh keputusan pembelian $\left(\dot{\eta}_{1}\right)$ terhadap minat beli ulang konsumen pada JG Motor Group ( $\left.\dot{\eta}_{2}\right)$ adalah sebesar 79,39\%. Sedangkan sisanya sebesar $20,61 \%$ dipengaruhi oleh faktor lain di luar model penelitian.

\section{PEMBAHASAN}

Hasil analisis deskriptif menunjukkan bahwa secara umum kualitas pelayanan dan citra toko masuk dalam kategori baik begitu juga keputusan pembelian dan minat bheli ulang pada JG Motor Group secara umum sudah relatif baik. Pada dasarnya jawaban respoden terhadap seluruh item pernyataan yang ada sebagian besar menjawab dengan skor antara 5 sampai dengan 6. Hal ini menandakan bahwa responden menjawab dengan kriteria cukup dan baik, dengan demikian respon dari responden cukup positif atau responsif. Dengan demikian bahwa rata-rata penilaian dari seluruh responden terhadap seluruh item pertanyaan memberikan penilaian yang baik. Namun demikian masih ada beberapa responden yang menjawab skor 3 dan 4. Hal ini menandakan respon terhadap berbagai item pernyataan belum baik.

\section{Pengaruh Kualitas Pelayanan terhadap Keputusan Pembelian}

Dari hasil pengujian analisis jalur menunjukan bahwa kualitas pelayanan berpengaruh terhadap keputusan pembelian yaitu sebesar $32,40 \%$. Angka ini menunjukan bahwa perubahan varian dari keputusan pembelian dapat dijelaskan melalui perubahanperubahan dari variabel-variabel yang tercakup dalam variabel kualitas pelayanan, sedangkan sisanya sebesar $67,60 \%$ dapat dijelaskan melalui variasi perubahan yang terjadi pada variabel lainnya variabel yang belum tercakup dalam penelitian ini.

Hubungan antara kualitas pelayanan dan keputusan pembelian dapat dikatakan bahwa suatu produk layanan, memiliki dampak pada kehendak untuk menggunakan layanan yang sama di masa yang akan datang. Karena pada dasarnya perilaku yang lampau dapat mempengaruhi minat (intention) secara langsung dan perilaku yang akan datang (future behavior).

Dengan demikian kualitas pelayanan merupakan tolak ukur dalam menentukan keputusan pembelian atau tidaknya seorang pengguna jasa, karena melalui kualitas pelayanan akan dapat menilai kinerja dan merasakan puas atau tidaknya mereka dengan layanan yang diberikan oleh penyedia jasa.

Ruyter et al. (1999) mengemukakan tentang kaitan antara kualitas layanan dan minat beli. Dalam penelitiannya, diungkapkan bahwa kualitas layanan yang baik akan mendorong minat beli konsumen. Jika outlet telepon seluler mampu memberikan layanan yang berkualitas, seperti adanya pengenalan produk yang baik, outlet yang nyaman, serta pemberian garansi dan servis yang memadai, diharapkan mampu mendorong konsumen untuk membeli produk tersebut. 


\section{Pengaruh Citra Toko terhadap Keputusan Pembelian}

Dari hasil pengujian analisis jalur menunjukan bahwa citra toko berpengaruh terhadap keputusan pembelian yaitu sebesar 45,58\%. Angka ini menunjukkan bahwa perubahan varian dari keputusan pembelian dapat dijelaskan melalui perubahanperubahan dari variabel-varaibel yang tercakup dalam citra toko, sedangkan sisanya sebesar 54,42\% dapat dijelaskan melalui variasi perubahan yang terjadi pada variabel lainnya yang belum tercakup dalam penelitian ini.

Membangun citra yang baik di mata konsumen maupun publik juga penting untuk menciptakan keputusan pembelian konsumen. Citra dapat mempengaruhi persepsi konsumen, sehingga citra dapat mempengaruhi proses pembelian suatu produk dan jasa. Memelihara citra toko merupakan salah satu alat yang terpenting bagi perusahaan untuk menarik dan memenuhi kebutuhan konsumen.

Reputasi perusahaan sangat penting dari sudut pandang pelanggan untuk memberikan gambaran terhadap kualitas produk atau jasa yang dihasilkan. Reputasi perusahaan secara langsung membentuk kepercayaan pelanggan terhadap produk atau jasa dari perusahaan sehingga akan mempengaruhi pertimbangan pelanggan dalam menentukan pilihan.

\section{Pengaruh Kualitas Pelayanan dan Citra Toko terhadap Keputusan Pembelian}

Pengaruh secara simultan variabel kualitas pelayanan dan variabel citra toko terhadap keputusan pembelian adalah sebesar $77,98 \%$, sisanya sebesar $22,02 \%$ dipengaruhi oleh faktor lain. Dengan demikian dapat disimpulkan keputusan pembelian dipengaruhi secara positif dan signifikan oleh kualitas pelayanan dan citra toko.

Pengaruh citra toko terhadap keputusan pembelian ternyata lebih besar daripada pengaruh kualitas pelayanan. Ini berarti keputusan pembelian konsumen untuk membeli motor di JG Motor Group lebih banyak mempertimbangkan citra toko daripada kualitas pelayanan. Hasil penelitian ini sejalan dengan hasil penelitian Yuticia (2002) yang menyatakan bahwa kualitas pelayanan, harga, citra produk, dan lokasi berpengaruh positif terhadap keputusan pembelian. Penelitian Bao (2010) menyatakan bahwa pembeli yang mempunyai citra merek yang tinggi akan menimbulkan minat beli.
Jika sebuah merek sudah dikenal akan tersimpan benak konsumen, ada asosiasi tertentu terhadap sebuah merek untuk membedakannya dengan merek yang lain. Konsumen akan mempersepsikan dengan kualitas yang tinggi dan membuat mereka merasa puas maka merek tersebut. Sutantio (2004) menyatakan bahwa reputasi dari perusahaan dalam sudut pandang pelanggan dapat dijadikan jaminan bagi pelanggan untuk menilai kualitas produk atau jasa. Hadi (2010) mengemukakan tentang kaitan antara kualitas layanan dan minat beli. Dalam penelitiannya, diungkapkan bahwa kualitas layanan yang baik akan mendorong minat beli konsumen. Youjae (2000) menunjukkan kaitan antara minat beli dan keputusan pembelian. Minat beli konsumen yang tinggi akan mendorong konsumen membeli suatu produk.

Kaitan antara citra merek dengan keputusan pembelian dikemukakan Pujiyono (2012). Dikemukakan bahwa citra merek akan berpengaruh langsung terhadap tingginya keputusan pembelian terhadap suatu produk. Hal tersebut didukung oleh pendapat Rasouli (2012) yang menyatakan bahwa perkembangan pasar yang demikian pesat mendorong konsumen untuk lebih memperhatikan citra merek dibandingkan karakteristik fisik suatu produk dalam memutuskan pembelian. Hal tersebut menjustifikasi pengaruh citra merek terhadap keputusan pembelian.

\section{Pengaruh Keputusan Pembelian terhadap Minat Beli Ulang}

Berdasarkan hasil penelitian, terlihat besarnya pengaruh keputusan pembelian terhadap minat beli ulang adalah sebesar 79,39\% sedangkan sisanya sebesar 20,61\% dipengaruhi oleh faktor lain. Dengan demikian dapat disimpulkan minat beli ulang dipengaruhi secara positif oleh keputusan pembelian.

Hasil penelitian dari Bao et al. (2010) menemukan bahwa selain pengaruh tidak langsung melalui persepsi kualitas pelayanan, citra toko memiliki pengaruh langsung positif terhadap tindakan pembelian. Selain itu pula Berman et al. (2007:600) komponen dari store image dapat membuat toko menarik sehingga dapat mempengaruhi minat beli konsumen menjadi keputusan pembelian konsumen pada saat melakukan kegiatan berbelanja.

Penelitian yang dilakukan oleh Hadi (2010) menunjukkan kaitan antara keputusan pembelian dan minat beli. Minat beli konsumen yang tinggi akan mendorong konsumen membeli suatu produk. 
Sebaliknya, minat beli konsumen yang rendah akan mencegah konsumen untuk membeli produk.

\section{KESIMPULAN}

Berdasarkan dari data deskriptif, hasil analisis data dan pembahasan hasil penelitian yang telah dijabarkan maka kualitas pelayanan, citra toko, keputusan pembelian, dan minat beli ulang konsumen pada sepeda motor Yamaha di JG Motor Group berdasarkan penilaian konsumen sudah dikatakan baik. Indikator yang paling berpengaruh terhadap variabel laten kualitas pelayanan adalah keinginan dan kesigapan karyawan untuk membantu konsumen memberikan informasi yang jelas dan lengkap tentang sepeda motor Yamaha yang dibutuhkan oleh konsumennya, sedangkan Indikator kualitas pelayanan yang masih belum optimal adalah kemudahan mengakses produk, hal ini dimungkinkan karena tidak semua konsumen memiliki dan dapat menggunakan fasilitas online, dan kebanyakan konsumen datang langsung ke outlet JG Motor untuk mengkomfirmasi pengiriman sepeda motor yang telah mereka beli.

Citra toko dari JG Motor Group berdasarkan penilaian konsumen sudah cukup baik, dengan Indikator kewajaran harga yang ditawarkan merupakan indikator yang paling berpengaruh terhadap citra toko. Mayoritas konsumen menilai bahwa harga produk yang ditawarkan masih terkesan mahal. Indikator citra toko yang terendah adalah program kupon.

Keputusan pembelian konsumen pada sepeda motor Yamaha di JG Motor Group masih cukup tinggi. Alternatif keunggulan produk merupakan indikator yang paling berpengaruh terhadap keputusan pembelian. Hal ini disebabkan karena banyaknya sepeda motor yang beredar di pasaran dengan mengusung berbagai keunggulan-keunggulan tentunya menjadi perhatian utama dari para konsumen untuk melakukan perbandingan terlebih dahulu. Indikator keputusan pembelian yang paling rendah pengaruhnya adalah kepuasan terhadap produk.

Konsumen sepeda motor Yamaha termasuk konsumen yang memiliki loyalitas, namun masih dalam kategori loyalitas tersembunyi karena tingkat pembelian ulang mereka masih belum tinggi. Bentuk minat beli ulang mereka hanya sebatas kemungkinan untuk mencoba bukan untuk melakukan pembelian di waktu yang akan datang.
Pengaruh kualitas pelayanan dan citra toko terhadap keputusan pembelian konsumen pada JG Motor Group secara parsial maupun simultan sebesar $77,98 \%$, sisanya sebesar $22,02 \%$ dipengaruhi oleh faktor lain. Dengan demikian dapat disimpulkan keputusan pembelian dipengaruhi secara positif dan signifikan oleh kualitas pelayanan dan citra toko. Pengaruh citra toko terhadap keputusan pembelian ternyata lebih besar daripada pengaruh kualitas pelayanan. Ini berarti keputusan pembelian konsumen untuk membeli motor di JG Motor Group lebih banyak mempertimbangkan citra toko daripada kualitas pelayanan. Sedangkan pengaruh keputusan pembelian terhadap minat beli ulang pada JG Motor Group adalah sebesar 79,39\% sedangkan sisanya sebesar $20,61 \%$ dipengaruhi oleh faktor lain. Dengan demikian dapat disimpulkan minat beli ulang dipengaruhi secara positif oleh keputusan pembelian

\section{DAFTAR PUSTAKA}

Bao, Youngcuant et al. 2010. Motivating Purchase of Private Brands: Effects of Store Image, Product Signatureness, and Quality Variation. Journal of Business Research, 64: 220-226.

Bloemer dan Schroder. 2002. Lingking Perceive Service Quality and Service Loyalty: A Multidimensional Perspective, European Journal of Marketing, Vol.33 No.11/12 International Journal of Bank Marketing Vol. 16 No.7

Ferdinan, Augusty. 2002. Manajemen Pemasaran: Sebuah Pendekatan Stratejik", Research Paper Series, Program Magister Manajemen Universitas Diponegoro, Semarang.

Ghozali, Iman. 2005. Aplikasi Analisis Multivariate dengan Program SPSS, Edisi Ketiga, Semarang: Badan Penerbit Universitas Diponegoro.

Hadi, Prasetyo. 2010. Pentingnya Brand Loyalty Terhadap Minat Beli Ulang. Jurnal Riset Ekonomi dan Bisnis, 10(1): Maret.

Haynes, R. M., and E. A. Thies. 2006. Management of Technology in Service Firm. Journal of Operation Management. 10(3): 388-397.

Kotler, Philip dan Kevin Lane Keller yang dialihbahasakan oleh Bob Sabran. 2009. Manajemen Pemasaran, Edisi Ketiga Belas, Jakarta: Erlangga. 
Lupiyoadi, Rambat dan Hamdani. 2007. Manajemen Pemasaran Jasa. Edisi 1. Jakarta: Salemba Empat.

Oliver, L. Ricahrd. 2010. Cognitif Affective and Atribute Base of The Satisfaction Respons, Journal of Customer Research, 20: 418-430.

Pujiyono dan Andy Kridasusila. 2012. Analisis Pengaruh Kualitas Layanan Terhadap Minat Pembelian Ulang Dengan Kepuasan Pelanggan Sebagai Variabel Intervening (Studi Kasus di Toko Alfamart Jati). Dinamika Manajemen, 1(4): 106-114.

Rasouli, Dizaji, Mohammad, et al. 2012. Evaluating the Affective Elements on the Repurchase Intention of the Costumer: Wang Model Processing in Iran's Mobile Industry. Journal of Basic and Applied Scientific Research.
Sutantio, Magdalena. 2004. Studi Mengenai Pengembangan Minat Beli Merek Ekstensi; Studi Kasus Produk Sharp di Surabaya. Jurnal Sains Pemasaran Indonesia, III.

Yusticia, Antofany et al. 2010. Pengaruh Persepsi Konsumen Terhadap Atribut Produk Pada Sikap Terhadap Produk Dan Niat Pembelian Ulang: Studi Empirik Pengambilan Keputusan pada Kategori Produk Daging Olahan Beku, Buletin Peternakan. 34(2): 131-137.

Youjae, Yi and Suna La. 2004. What Influences the Relationship Between Customer Satisfaction and Repurchase Intention? Investigating the Effects of Adjusted Expectations and Customer Loyalty, Psychology \& Marketing, Seoul National University, 21(5): 351-373. 